\title{
MONEY SANCTIONS FOR BREACH OF CONTRACT IN A COMMUNIST ECONOMY
}

\author{
BERNHARD GROSSFELD $\dagger$
}

THE Western jurist with a civil or common law background approaching for the first time the contract law of a communist country, is inclined to assume that liability for damages for breach of contract, if it exists at all, cannot be of any great importance. The economy in these countries is almost completely centralized; all economic activity, indeed every business transaction, is governed by the "plan," and all enterprises of any importance are property of the state. The Western observer generally will be surprised to learn that an elaborate system of contracts governs the relations between the state-owned enterprises. We traditionally connect the notion of contract with a free economy, based on private property, individual activity, and competition. But even more striking is that liability for damages is of central importance under the contract law of a communist nation. For we would frequently think that contractual obligations between state-owned enterprises in such an economy would be enforced only by such public measures as police action and criminal punishment. Moreover, we are accustomed to take for granted that the main purpose of money remedies for breach of contract is to compensate injured parties and to deter contractual parties from breaching. In an economy where all the main enterprises are state property, however, it seems inconceivable that the main purpose of remedies for breach of contract could be the compensation of losses. The payment of damages from one state-owned enterprise to another can result only in transfer of the financial resources of the state from one organ to another. Why, then, introduce money damages for breaches of contracts, with all the difficulties arising when they are claimed and with all the institutions necessary for their settlement or enforcement? How can a system of contractual liability for damages work effectively in a communist economy? What can be its purpose? What are its peculiarities and effects?

The contract law of East Germany offers a good opportunity to examine these questions, since that state now has a completely centralized economy based on staté-owned enterprises. The observations here reach far beyond East Germany, however, providing a key for a better understanding of similar questions in all European countries under communist control, because the contractual systems of all these countries are at present in nearly the same stage of development. ${ }^{1}$

\section{The System of Contracts in East Germany}

The East German law of contracts is now regulated by the Statute on the System of Contracts in the Socialist Economy (Statute of Contracts) of

$\dagger$ This article was prepared with the helpful guidance of Professor Kazimierz Grzy. bowski of the Yale Law School and was inspired by an unpublished seminar report of Miss Ingrid Sydow at the University of Münster, Germany.

1. Drobnig, Der Vertrag in einer plangelenkten Staatszirtschaft, 15 JunstenzerTUNa 233, 240 (1960). 
December 11, 1957.2 More than half its 97 sections deal elaborately with the contractual responsibilities of the parties and the remedies for breach of contracts, thus indicating by sheer volume the paramount importance of contractual responsibility. By far the most important sanctions for breach of contract are monetary damages and penalties. ${ }^{3}$

This system of contract law is the final result of a development which started in 1945, when East Germany fell under Soviet domination. Immediately after the Soviet occupation a completely centralized and planned economy was introduced. The economic goals set forth in the plan were executed exclusively by administrative, bureaucratic means. Every business transaction was regulated by special administrative directives in which all particulars were meticulously fixed. ${ }^{4}$ This system worked satisfactorily to a certain extent, but only so long as the economy as a whole was not too complicated and differentiated. With the growth of the economy, the slowly rising standard of living, and the complexity of industrial and consumer demands in the modern industrial age, other methods of economic ordering and regulation became necessary. Thus, in accordance with previous experiences in the Soviet Union, ${ }^{5}$ a system of contracts was introduced at the end of 1951.6 This change was the expression of a certain decentralization and an attempt to give some scope to individual initiative. The experiences of this early stage of the contract system ultimately led to the promulgation of the Statute of Contracts.

It is impossible within the scope of this article to describe in detail the functions and the position of contract in a communist economy. It is, nevertheless, necessary to deal briefly with the relationship between plan and contract, as this relationship is the basis for the functioning of the system of contracts. The plan holds a central position in the East German economy. It expresses the governmental economic policy and fixes, with the help of binding directives, the course of the country's economic development. The function of the contract, in turn, is to implement in detail the directives of governmental policy as expressed in the plan. ${ }^{8}$ The introduction of the system of contracts is designed to eliminate from the plan those specifications which are important only

2. Gesetz über das Vertragssystem in der sozialistischen Wirtschaft (Vertragsgesetz) vom 11. Dezember 1957. [1957] 1 Gesetzblatt der Deutschen Demokratischen Republik 627 (Ger. Dem. Rep.). [Hereinafter cited as Statute of Contracts].

3. Panzer, Die Verantwortlichkett für Dritte in den Vertragsverañuttsisseni ZWISCHEN SOZIALISTISCHEN WIRTSCHAFTSORGANISATIONEN 45 (Deutsches Institut für Rechtswissenschaft, Schriftenreihe Zivilrecht, Heft 9, 1958).

4. Drobnig, stipra note 1, at 233. SpITzNer \& PANZER, Zur Wirtscinaftslertender: Tätigkeit des StaAtlichen Vertragsgerichts 14 (1961).

5. SitzZNER \& PANZER, op. cit. supra note 4, at 12 .

6. Verordnung über die Einführung des Allgemeinen Vertragssystems für Warenlieferungen in der volkseigenen und der ihr gleichgestellen Wirtschaft vom 6 . Dezember 1951 [Regulation concerning the introduction of a general system of contracts ... .]. [1951] Gesetzblatt der Deutschen Demokratischen Republik 1141 (Ger. Dem. Rep.).

7. Bratus \& Lunz, FrageN des Wirtschaftsvertrages 10 (Deutsches Institut für Rechtswissenschaft, Schriftenreihe Zivilrecht, Heft 6, 1956).

8. GRZYBOWSKI, SOVIET LEGAL INSTITUTIONS 87 (1962). 
between a particular purchaser and a particular seller, as, for instance, the precise date of delivery, or the particular type, quality, and packaging of the goods. ${ }^{9}$ Moreover, the contract serves as a means for disclosing mistakes and errors in the general planning and permitting their correction. ${ }^{10}$

The most important state organ in the administration of the system of contracts is the "State Contract Court," which resolves disputes arising out of contractual arrangements. ${ }^{11}$ Since conflicts are handled in nonadversary proceedings and decisions are called "awards of arbitration"12 controversy still exists as to the fundamental nature of the contract court. In section 1(1) of the legislative decree concerning the contract court the court is identified as a "central organ of governmental administration." It is apparently for this reason that all commentators agree that the designation "court" is misleading. Some authors ${ }^{13}$ deny completely its character as a court. Notwithstanding these controversies, unanimity exists as to its main purpose: Its task is to lead and educate the socialistic economy by means of its decisions. ${ }^{14}$ The contract court plays an affirmative role in representing the interests of the state, beyond the mere interests of the parties involved, during each proceeding. In the process, it locates the source of error that led to the breach, proposes measures to prevent further breaches, and, in addition to rendering an opinion, may even organize an exchange of experiences with other enterprises. ${ }^{16}$ Moreover, the court continually observes the effectiveness of the contract system as a whole so that it is in a position to make proposals for improvement. ${ }^{10}$

\section{The Economic Basis of Contractual Responsibility for Damages}

The introduction of the system of contracts in 1951 was closely connected with a fundamental change in the status of the state-owned enterprises in their relation to the state and to each other. This change, in the official East

9. Bratus \& Lunz, op. cit. supra note 7, at 8; Drobnig, supra note 1, at 234-35; Hemmerling, Vertragspfltcht UNd Vertragsabschluss im VertraGsGesetz 22-23 (1958).

10. Bratus \& Lunz, op. cit. supra note 7, at 11 ; Drobnig, supra note 1 , at 236.

11. Verordnung über das Staatliche Vertragsgericht (Vertragsgerichtsverordnung) vom 22. Januar 1959 [Regulation concerning the State Contract Court]. [1959] 1 Gesetzblatt der Deutschen Demokratischen Republik 83 (Ger. Dem. Rep.). The State Contract Court consists of the Central State Contract Court (Zentrales Staatliches Vertragsgericht) as the court of last resort and the District Contract courts (Bezirksvertragsgerichte). The procedure is regulated by the Verordnung über das Verfahren vor dem Staatlichen Vertragsgericht (Vertragsgerichtsverfahrensordnung) vom 22. Januar 1959 [Regulation concerning the procedure before the State Contract Court]. [1959] 1 Gesetzblatt der Deutschen Demokratischen Republik 86 (Ger. Dem. Rep.).

12. "Schiedssprüche."

13. StitzNer \& PANzer, op. cit. supra note 4, at 40 ; contra, Dornberger, Zur quirtschaftsleitenden Tätigkeit des Staatlichen Vertragsgerichts, 11 STAAT UND REcuT 1091, 1100 (1962).

14. Klinger \& Panzer, Zur wirtschaftsleitenden Tätigkeit des Staatlichen Vertrags-

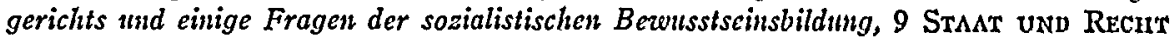
459, 461 (1960); cf. 5 Das Vertragssystem 89, 90 (1961).

15. SPITZNER \& PANZER, op. cit. supra note 4, at 34-35.

16. Id. at 36 . 
German terminology, is described as the introduction of the "principle of economic accounting."17 Every state owned enterprise now has the duty to work profitably within the framework established by the plan and in accordance with the economic goals it sets forth. Every enterprise has to maintain its own accounts showing gains and losses. For this purpose all enterprises have been equipped with separate assets and money. ${ }^{18}$ Thus enterprises have become comparable-at least to a certain extent-to independent privatelyowned enterprises. The principle of economic accounting is generally held to have been the decisive step in establishing contractual liability for damages as a means of "control through the Mark."19 The policy behind this innovation was that a higher overall efficiency of the economy could be achieved only by giving each state-owned enterprise a greater independence and by making it responsible for its operations. But the new concept of the socialistic enterprise as an independently operating, externally responsible economic unit, it was believed, could be successful only if the workers in the enterprise had an interest in its success. Thus the "principle of material interest"20 was introduced alongside the principle of economic accounting. This label describes an attempt to set up a system of economic incentives for the directors, employees, and workers of the enterprise. This was tried originally by the introduction of the "director's fund," 21 which was designed to permit participation by the members of the enterprise in its financial success. Into this fund went a certain percentage of the profits the enterprise made through overfulfillment of its plan. ${ }^{22}$ The director's fund has since been replaced by the "enterprise premium fund,"23 which has a similar function. Each year a sum amounting to up to $6.5 \%$ of the total wages planned for that year ${ }^{24}$ can be paid into the fund. ${ }^{25}$ The amount actually paid in depends upon how the enterprise performed during the year under the plan and how much "profit" it earned. The fund itself

17. "Prinzip der wirschaftlichen Rechungsführung." It was introduced by the Verordnung über Massnahmen zur Einführung des Prizips der wirtschaftlichen Rechnungsführung in den Betrieben der volkseigenen Wirtschaft vom 20. AIärz 1952 [Regulation concerning measures for the implementation of the principle of economic accounting ....]. [1952] Gesetzblatt der Deutschen Demokratischen Republik 225 (Ger. Dem. Rep.).

18. SPITZNER \& PANZER, op. cit. supra note 4, at 12.

19. Id. at 11 .

20. "Prinzip der materiellen Interessiertheit." Id. at 12.

21. "Direktorfond," introduced by the Verordnung über die Bildung und Verwendung des Direhtorfonds in den Betrieben der volkseigenen Wirtschait im Planjahr 1952 vom 25. März 1952 [Regulation concerning the establishment and use of the director's fund ....]. [1952] Gesetzblatt der Deutschen Demokratischen Republik 229 (Ger. Dem. Rep.).

22. Regulation concerning the establishment and use of the director's fund ..., stpro note $21, \S 3$.

23. "Betriebsprämienfond," introduced by the Verordnung über den Betriebsprämienfonds sowie über den Kultur- und Sozialfonds in den volkseigenen und ihnen gleichgestellten Betrieben vom 11. Mai 1957 [Regulation on the enterprise premium fund. . .]. [1957] 1 Gesetzblatt der Deutschen Demokratischen Republik 289 (Ger. Dem. Rep.).

24. "geplante Jahreslohnsumme.".

25. Regulation on the enterprise premium fund . . ., supra note $23, \S 10$. For more technical details, see Pficke, Materielle. Interessierung und materielle Veronturortung, 1 Das Vertragssystear 1 (Heft 2, 1957). 
is earmarked for distribution among members of the enterprise according to their individual performance, ${ }^{26}$ generally by awarding prizes to outstanding directors, technical personnel, foremen, and workers for innovations and stuggestions for improvements. ${ }^{27}$

The fact that the amount available for the enterprise premium fund depends on the profits of the enterprise is the cornerstone for the effective functioning of contractual liability for damages, since damages caused by a breach of contract diminish the profit of the injured party and proportionally decrease the means available to the fund. This detrimental influence on the gains of the enterprise and its premium fund can be compensated through the payment of a certain amount of money by the responsible enterprise, restoring the profit to the original level. Such payment simultaneously reduces the gains of the responsible enterprise and the amount available for its premium fund. Thus, the adverse consequences fall ultimately on the enterprise responsible for the breach. In this manner the money sanctions for breach of contract acquire real meaning. 28

\section{The Purpose of Damages and Penalties for Breach of Contract}

The foregoing discussion seems to indicate that there is no great difference in the purpose of money sanctions for breach of contract between a civil or common law system, and the East German system. In both cases they serve to compensate losses. But this compensatory function does not have the same paramount importance in East Germany as it has in a western economy.

In a communist economic system the payment of damages can by no means compensate completely the damage incurred. The damage to the society as a whole, for example, cannot be compensated ${ }^{20}$ for every breach of contract disturbs a certain established pattern and demands an increased effort to overcome its consequences and to re-create order. The liquidation of the damages absorbs additional energy and time which could have been better used-if the damage had not occurred - for constructive activity. ${ }^{30}$ Moreover, the goods which could not be produced as a result of the breach of contract are missing in the final balance of the plan, or can be produced only at the expense of other goods. The fact that these arguments might equally be given in at western legal system throws some doubt on the contention that the most important goal of the money sanctions for breach of contract is compensation; the relevance of these arguments is at least not restricted to the law of a planned communistic economy. ${ }^{31}$ But there is another-I am inclined to say "unique"-

26. Regulation on the enterprise premium fund. . ., supra note $23, \S 20$.

27. Regulation on the enterprise premium fund. . , supra note $23, \S 21$.

28. Pflicke, Materielle Interessiernng und Sanktionen, 1 DAS Vertragssystex 5 (Heft 3, 1957).

29. Panzer, op. cit. supra note 3 , at 17.

30. Ibid. See also Chalfina, Wesen und Bedeutung des Vertrages ina SowJETISCHEN SoztalistisChen ZTVLRECHT 21-22 (Deutsches Institut für Rechtswissenschaft, Schriftenreihe Zivilrecht, Heft 8, 1958).

31. Cf. Grossfeld, Die Privatstrafe 76 (Arbeiten zur Rechtsvergleichung, 1961). 
feature in a communist economy that makes compensation itself virtually impossible-the existence of a comprehensive plan by which the economy is ruled. In a free, competitive economy, with free access and exchange of goods, nearly every good can be evaluated and replaced by a certain amount of money. Consequently, in such an economic system a purchaser whose supplier breaches a contract can generally purchase the same goods from another supplier, provided the damages he sustained are compensated. Thus in our western legal systems a purchaser very often does not have a vital interest in the specific performance of the contract; whether he receives from the seller the goods he wanted or their money value may make little difference to him. This is not the case in a completely planned economy where there does not exist a free flow of goods available on the open market. If one particular producer or supplier fails to perform his contractual duties there are no others to whom the buyer can turn. Money, therefore, is no equivalent for the product itself. Thus the tasks imposed upon the enterprise by the plan cannot be accomplished when the enterprise receives money instead of the goods it needs for production, and from this this it follows that in such an economy actual performance of every contract is of greatest importance. ${ }^{32}$ This "principle of specific performance" 33 is the basic principle of the communist system of contracts. It represents the categorical demand of the law that the goods which are to be delivered must not be replaced by money damages. ${ }^{34}$ Thus even an express agreement between the parties to a contract concluded under the plan that specific performance will be waived in favor of an equivalent in money is void. ${ }^{35}$ The money compensation is conceived exclusively as an "emergency measure,"36 a "last resort" when specific performance is virtually impossible. ${ }^{37}$

These unique features of the economic system demonstrate that the main purpose of the money sanctions for breach of contract cannot be compensation for losses. Rather, the emphasis shifts to prevention of losses or "education." The main task of money sanctions becomes the enforcement of contractual discipline, ${ }^{39}$ for the understanding is that the more difficult it is to compensate damage the more must be done to prevent it. The money sanctions serve their purpose best, therefore, when they prevent occurrence of a breach of contract:40 When a party does fail to perform the contract and has to pay damages, they

32. Chalfina, op. cit. supra note 30, at $21 ; 1$ Genkin, Bratus, Lunz \& Nowtzks, Sowjetisches ZIVILRECHT 493 (1953); Knapp, Das Problem der sogenannem realen Erfiillung, 9 NEUE JUSTIZ 463 (1955); PANZER, op. cit. sitpra, note 3, at 17; Reimers, Uber die Gefährdung der Vertragserfülllung und siber das mitwirkende Versciulden im Allgemeinen Vertragssystem, 7 NEUE JUSTIz 486, 489 (1953).

33. "Prinzip der realen Vertragserfüllung"; literally, "principle of actual fulfillment."

34. Knapp, sipra note 32, at 464-65.

35. Ibid. 1 GENKIN, BRATUS, LUNz \& Nowizkr, op. cit. sipra note 32, at 495.

36. 1 GENKIN, BRATUS, LUNZ \& NowizET, op. cit. supra note 32, at 493.

37. Ibid.

38. Pflicke, sipra note 28, at 5; PANZER, op. cit. supra note 3, at 17-18.

39. Knapp, supra note 32 , at 465 .

40. Pflicke, $Z u$ den sibjektiven Voraussetsungen der wechselseitigen matcriellen Verantwortlichkeit der sozialistischen Betriebe, 6 DAs VertraGsSYSTEMr 225, 226 (1962). 
function as a "form of social criticism," 41 as a means of "education through the Mark." ${ }^{2}$ Simultaneously, of course, there is a compensatory effect, ${ }^{13}$ but, in direct contrast with the Western systems, compensation is warranted only if it can serve an educational purpose. ${ }^{44}$ Moreover, the effects of the money sanction go far beyond the particular contract in question, because the contract and the plan stand in very close nexus. Through the contracts the necessary combination between the central direction of the economy by the state and the economic independence of the enterprises is realized. ${ }^{45}$ When concluding contracts within the framework of the plan, each enterprise determines the precise content of its share in the implementation of the plan. ${ }^{46}$ The contract is thus a means of economic planning, ${ }^{47}$ an instrument by which the purposes of the state can be realized. ${ }^{48}$ Compensation for damages, then, is not paid for the benefit of the injured party, but constitutes an attempt by the state to use the individual interest as a tool to achieve social control, to secure the fulfillment of the plan. The party to the contract who sues for damages fulfills a "public" task; his own interest is satisfied only where it serves the greater goals of the society.

\section{The Peculiarities of Damages and Penalties for BREACH OF CONTRACT}

\section{A. The Fault Principle}

Liability is based on the fault principle. ${ }^{40}$ Section $37(1)$ of the Statute of Contracts is merely declarative of the mutual responsibility of the parties for the performance of their contractual duties. But section $37(2)$ vo adds that,

41. See Judgment of March 28, 1960, Zentrales Staatliches Vertragsgericht, 4 DAs VertRAGSSYSTEM 216, 217 (1960) (Ger. Dem. Rep.).

42. See Pflicke, supra note 28, at 5; cf. Judgment of Sept. 7, 1959, Bezirksvertragsgericht Dresden, 3 Das Vertragssystems 383 (1959) (Ger. Dem. Rep.).

43. Spitzner, Die materielle Verantwortlichkeit der Betriebe fïr ihre Kooperalionsverpfichtungen, 6 DAs Vertragssystem 193, 195 (1962); Panzer, Verschulden ist Voraussetzung fïr die vertragliche Verantwortlichkeit, 6 DAS VERTRAGSSYSTEM 196, 197 (1962).

44. Mitteilung des Zentralen Staatlichen Vertragsgerichts $\mathrm{Nr}$. 44/59 vom 14. Oktober 1959 zur Anwendung der $\$ \S 37$ und 38 Abs. 1 Vertragsgesetz [Opinion of the Central Contract Court concerning the application of $\$ \S 37,38(1)$ of the Statute of Contracts], r'cprinted in SPITZNER \& PANZER, op. cit. supra note 4, at 181, 182.

45. StitzNer \& PANZER, op. cit. supra note 4, at 13.

46. Such, Das Vertragssystem-Instrument der Staatlichen Leitung sur Entwicklung der Initiative und der Tatkraft der Volksmassen, 3 DAs VeRTRAGsSYSTEM 257, 259 (1959).

47. Spitzner \& Panzer, op. cit. supra note 4, at 14.

48. Ibid. Such, supra note 46 , at 259.

49. PANzer, op. cit. supra note 3, at 34; Pficke, supra note 25, at 3.

50. Statute of Contracts $§ 37$ :

(1) Die Vertragspartner sind einander für die Einhaltung der Verpflichtungen aus dem Vertrage verantwortlich.

(2) Der Schuldner wird von der Verantwortlichkeit befreit, wenn er nachweist, dass die Nichterfüllung oder nicht gehörige Erfüllung durch Umstände bedingt ist, dio er nicht abwenden konnte. Dieser Nachweis ist ausgeschlossen, soweit in den folgenden Bestimmungen festgelegt ist, dass der Schuldner in bestimmten Fällen von der Verantwortlichkeit nicht befreit wird. 
except in situations which are subsequently enumerated in the statute, ${ }^{31}$ the defendant is relieved from all liability when he proves that the breach of contract was caused by circumstances "which he could not avoid." Whether the failure of performance is caused by negligence or by an intentional act is irrelevant. ${ }^{52}$

The introduction of the fault principle was not achieved without dispute. In Soviet jurisprudence there had been a tendency to call the fault principle "bourgeois" and "unsocial," without any value in a socialist civil law. ${ }^{63}$ Consequently, in 1951, when the system of contracts was first introduced, it was provided that the obligation to pay penalties or damages should arise regardless of whether there was fault by the defendant.54 But only a few weeks later the fault principle was introduced, ${ }^{55}$ and the traditional arguments favoring strict liability were rejected.

One such argument reflected the usefulness of the money sanction as an indicator of breaches of contracts and thus as a means of centralized state control. This worked as follows. In East Germany the state-owned enterprises do not have the right to effect direct financial transactions among themselves. Every payment has to be effected through the central bank, the "Deutsche Notenbank." The transfer of a penalty or of damages from the account of one enterprise to that of another signals the breach of contract and the bank can inform the competent authorities. ${ }^{50}$ Strict liability operates as the most effective indicator because it signals to the authorities every disturbance in the performance of the plan by a corresponding "automatic" financial transaction. At least in theory this is so, and originally the theory may have worked quite well. But with the steadily rising number of financial transactions, the supervision of all accounts became far too costly, ${ }^{67}$ and thus had to be replaced with a more efficient form of control.

Another argument in favor of strict liability, which found strong support in the discussions before the final draft of the Statute of Contracts, was that strict liability is an excellent means for tracing all injurious consequences of a breach back to the enterprise in which the first cause intervened. Not only can the decisive first cause easily be detected, but the entire amount of damages which this first mistake caused by its impact on other enterprises at successive stages of production can be measured. ${ }^{68}$ But this argument, too, did not prevail, for it was feared that the causal principle would create an enormous task for the

51. See text at notes 71-92 infra.

52. Panzer, supra note 43 , at 200.

53. PANZER, op. cit. supra note 3 , at 32.

54. Drobnig, Der Vertrag in einer plangelenkten Staatswirtschoft, 15 Junustenzerrusic $233,238-39$ n.62 (1960).

55. Ibid.

56. Id. at 234; PANzer, DIE Verantwortlicekett für DrITte in deN VertragsverHÄLTNISSEN ZWISCHEN SOZLALISTISCHEN WIRSCHAFTSORGANISATIONEN 45 (1958). See generally SaArson, Grundzüge des Mitrteldeutschen WIRtschaftsRechis 114-15 (1960).

57. Drobnig, stipra note 54 , at 237.

58. Freytag, Die Grundsätze der materiellen Verantwortlichkeit im Entzurf der neuen Vertragsverordnung, 10 NEUE JUSTIz 204, 205 (1956). 
administrators and courts, ${ }^{50}$ and would lead to a tremendous burden in the basic materials industry, in which the first cause generally would appear. And here the breach would very often be due to factors that could not be avoided.00 Moreover, it was successfully argued in opposition to strict liability that the preventive and educational purpose of the money sanctions would be frustrated if an enterprise were held responsible for an act or failure that it could by no means avoid. Instead of fostering the energy and initiative necessary to overcome the difficulties that led to the breach, such a policy would promote indifference, since even the most diligent efforts would be without any influence on liability. ${ }^{61}$

Thus the attempt to assure a high educational effect for money sanctions is observable throughout the provisions of the Statute of Contracts. The general tendency is to make the responsibility as severe as possible within the framework of the fault principle. This tendency is reflected clearly by the measure of care which is required from every enterprise in the performance of its contracts. The standards for testing whether a breach of contract was avoidable are extremely rigorous. Rather than relating to the abilities of the particular individual or enterprise in question, they are objective standards ${ }^{62}$-the objective demands of commerce. ${ }^{63}$ It is not the "reasonably prudent man" who serves as the "objective" standard in a case involving an individual but the worker in a socialist enterprise displaying the greatest success in production. ${ }^{04}$ As to the responsibility of the enterprise, the standard requires a duty to make the utmost efforts and to display the highest possible concern for the fulfillment of the contract. A maximum exertion by the enterprise, ${ }^{05}$ even an extraordinary effort, ${ }^{86}$ is necessary, and this effort is evaluated from the standpoint of the society and its objective needs. ${ }^{67}$ Thus, for instance, an enterprise cannot contend as a defense that its technical equipment does not meet the present high standards of technology and science. ${ }^{88}$ The defendant is relieved from liability only when the breach is traceable to "unavoidable forces" or when the injured party himself was the cause. An "unavoidable force" in

59. PANZER, op. cit. supra note 56, at 33 .

60. Id. at 33-34. But the idea of tracing back the avalanche of damages to its starting point was not completely abandoned. As will be seen later, it reappeared in a somewhat mitigated form under the guise of another legal device-liability for third persons.

61. Hemmeritng, Grundfragen des Vertragssystems 77-78 (1958), cited in Hofmann \& Schneider, Book Review, 3 DAs Vertragssysteds 52, 54 (1959); PANzeR, op. cif. supra note 56 , at 33 ; Pflicke, supra note 25 , at 2 .

62. PANZER, op. cit. supra note 56, at 35-36.

63. Id. at 35 .

64. Ibid.

65. Pflicke, supra note 40 , at 230 , giving several examples.

66. Pflicke, Materielle Interessierning und materielle Verantwortung, 1 DAs VerTRAGSSYSTEM 3 (Heft 2, 1957).

67. PANZER, op. cit. supra note 56, at 36 .

68. Judgment of June 4, 1959, Zentrales Staatliches Vertragsgericht, 3 DAs VertraGsSYSTEM 219 (1959) (Ger. Dem. Rep.).

69. "unabwendbare Gewalt." 
defined in section 40 as an event that was unpredictable and could not be avoided either by the defendant or by others even through the taking of all precautionary measures which correspond to the latest knowledge of technology and science. $^{70}$

\section{B. The Main Extensions of the Fault Principle}

There are, however, a few sections of the statute that outwardly, at least, give the appearance of imposing strict liability. The most important is section $38(1),{ }^{71}$ according to which the defendant cannot be released from liability when the breach of contract was caused by circumstances within the enter.prise ${ }^{72}$ or by the organization of the enterprise for the implementation of the plan. ${ }^{73}$ This may be the case when a machine becomes defective or when other technical difficulties occur which are not of a completely extraordinary character. ${ }^{74}$ The same is true when the enterprise fails to hire the workers it needs to fulfill its contractual duties. ${ }^{\text {To }}$

The liability imposed by section $38(1)$, however, is doctrinally not regarded as strict liability, since this would be inconsistent with the educational concept of contractual liability. Instead, section $38(1)$ is construed as creating a conclusive presumption of fault. ${ }^{76}$ This interpretation is justified by the argument that fault is generally involved whenever a breach of contract is caused by an event within the sphere of the enterprise. Moreover, it is argued that outsiders could not realistically be expected to determine whether an enterprise has deployed all its energy and engaged all its reserves to avoid a technical breakdown. ${ }^{77}$ Finally, the presumption of fault may induce the enterprise to take the utmost care and foresight to avoid technical disturbances or to overcome their consequences. ${ }^{78}$

\footnotetext{
70. Statute of Contracts $\$ 40$.

71. Statute of Contracts $\S 38(1)$.

72. "Umstände des betrieblichen Geschehens." Ibid.

73. "Organisation der Planerfüllung." Ibid.

74. PANZER, op. cit. supra note 56, at 43; Pflicke, supra note 66 , at 4-5.

75. This latter rule is tempered only by such extraordinary circumstances as a shortage of labor caused, for example, by a suddenly occurring flu epidemic. This limitation fits well into the general rule that the enterprise is responsible only for disturbances which must be reckoned with in the usual course of events, PANZER, op. cit. supra note 56, at 43, and which can, at least theoretically, be influenced by the efforts of the enterprise. SPITzNER \& PANzer,

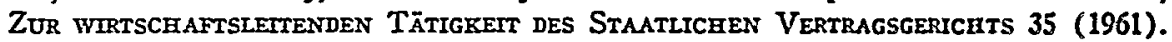
Thus, the responsibility stipulated in section $38(1)$ finds its limit where the "unavoidable force" begins. Pficke, supra note 66 , at 5 . As to the severity of this responsibility and the restricted interpretation of "unavoidable force," cf. Judgment of Jan. 12, 1959, Regierungsvertragsgericht, 3 DAS VeRTragssysteMr 90-91 (1959) (Ger. Dem. Rep.).
}

76. Drobnig, supra note 54 , at 238; HesrarerLING, op. cit. supra note 61 , at $96,98-99$, cited in Hofmann \& Schneider, supra note 61, at 54.

77. Pflicke, supra note 66 , at 4 .

78. Drobnig, supra note 54, at 238; PANZER, op. cil. supra note 56, at 43. 
This interpretation of section $38(1)$ shows that the fatult principle in the system is based on the assumption that every mistake-except those stemming from "unavoidable forces"70 - can be avoided and that every mistake that can theoretically be avoided must be avoided in practice. It goes without saying that this axiom and the demand drawn from it do not correspond to reality, and that very often the liability for breach of contract becomes strict liability in practice. The line between liability based on fault and strict liability in this system is by necessity very thin, and the dilemma it creates seems insoluble. On the one hand standards must be very high, bordering on strict liability, because there should be an inducement to exercise the utmost care. On the other hand this borderline must not be crossed, lest the educational purpose be frustrated. Yet the law creating such a dilemma seems itself unavoidable by the very nature of the basic economic system. The plan establishes a highly complicated system which is very sensitive to every disturbance. Even slight disarrangements can have serious consequences on the economy as a whole. Unlike a free, competitive economy where the risk is divided among many independently-operating, self-adjusting economic units, a completely planned economy does not have great elasticity, no "built-in buffers" which alleviate and limit losses. That is why the utmost care to avoid even minor failures is necessary. Only an élite is capable of meeting these demands; the average man with his mistakes, his deficiencies and his lack of social discipline has no place in this system. But this is only one side of the coin. The law cannot disregard completely the fact that most people are near average. There is a broad gap between the ideal, conceived as the standard, and reality. This gap must be closed by education or even stronger pressures, and the larger the gap the stronger must be the pressure to close it. Such pressures raise the danger, however, that people withdraw into resignation. Thus, ironically, the high standard of care which is indispensable to produce the necessary educational effect may be at the same time the greatest obstacle to its attainment.

The struggle to find a way between the Scylla of strict liability and the Charybdis of too low a standard of care can be seen in the difficulties that arose out of the relation of section 37 (the fault principle) to section 38 (1) (con* clusive presumption of fault). In the first year after the introduction of the Statute of Contracts the lower courts relied heavily on section $38(1)$, so that in practice the fault principle seemed to be abandoned. This practice simplified the task of the contract courts, because it enabled them to avoid examining defendants' claim that the mistake could not have been avoided under the given circumstances. ${ }^{80}$ It thus represented an avoidance by the courts of their basic duty to the State to identify the source of errors and to stimulate the discussion and adoption of corrective measures-the "educational" purpose of the Statute of Contracts and the contract courts. This practice produced a growing indifference toward the possibilities of corrective action among the

79. See note 75 supra.

80. Cf. Heuer \& Pflicke, $Z u$ den Aufgaben der Rechtswissenschaft bei der Verbesserung der Zusammenarbeit der Betriebe, 4 DAs VerTRAGSSYSTEM 204, 209 (1960). 
enterprises against whom the decisions were rendered. ${ }^{81}$ Finally, therefore, the Central State Contract Court intervened in 1959, declaring the extensive application of section $38(1)$ to be inconsistent with the main policy underlying contractual responsibility for damages, and directing that its application be restricted to exceptional cases. ${ }^{82}$ In the year following this opinion, section 37 formed the basis of decision in $87.8 \%$ of all cases in which contractual liability for damages was the main issue, and section $38(1)$ in only $12.2 \%{ }^{83}$ It is doubtful, however, whether the new directive represents a substantial change in the degree of ultimate responsibility of enterprises breaking contracts, ${ }^{84}$ since the contract courts are always free to apply section $38(1)$ after they find section 37 inapplicable. Nonetheless, the new development does at lenst represent a clear attempt to require the contract courts to locate the source of mistakes and explore ways of preventing them-thus assuring the performance of their educational tasks in the field of contractual responsibility. ${ }^{80}$

Another deviation from the fault principle is section $38(2)$, according to which the defendant is not relieved of liability if the breach of contract is caused by lack of money. It would seem that the lack of other resources causing a breach would be treated similarly, but it is not. The lack of other resources is excused because other resources are not at the free disposal of the enterprise in a planned economy. ${ }^{86}$ Although this is true also of money, its lack is uniquely regarded as conclusive evidence that, in the long run, the enterprise will not work efficiently to meet the standards of the plan, regardless of whether it has committed particular mistakes. ${ }^{87}$ The lack of money, then, is conclusively presumed to be caused by fault. 88

Finally, section $38(3)$ provides that the defendant is responsible if the breach of contract is caused by the unilateral directive of a superior administrative organ. This provision appears somewhat surprising, since the enterprise is legally bound to comply with the order, even if it results in a breach of contract. ${ }^{89}$ But its effects are offset by a requirement that the organ issuing a unilateral directive reimburse the enterprise for damages it had to pay..$^{90}$ The

81. Klinger \& Panzer, Zur wirtschaftslcitenden Tätigleit des Staallichen Veriragsgerichts und einige Fragen der sozialistischen Bcwnsstseinsbildung, 9 STANT UND RECrT 459, 466-69 (1960); see also Artzt, Die Verwirklichung der Veranfacorflichlecil des sosialistischen Industriebetriebes, 11 STAAT UND RECHT 489 (1962).

82. Opinion of the Central Contract Court concerning the application of $\S \S 37,38(1)$ ..., supra note 44.

83. Data from Spitzner, supra note 43, at 196.

84. Cf. Hofmann \& Schneider, stpra note 61, at 54.

85. See SPITZNER \& PANZER, op. cit. supra note 75, at 32-35.

86. See PANZzR, op. cit. supra note 56, at 91 .

87. Pflicke, supra note 66, at 5 ; PANZER, op. cit. supra note 56, at 39.

88. Drobnig, sipra note 54, at 238. Cf. Judgment of Oct. 17, 1956, Zentrales Staatliches Vertragsgericht, (Ger. Dem. Rep.), cited by PANzER, op. cit. supra note 56, at 39 n.123.

89. See Pflicke, supra note 66, at 6.

90. The methods of how this compensation is effected are extensively discussed in Wege, Zum finanziellen Ausgleich bei einseitigen Weisungen, 3 DAs VertraGssrstear 304 
purpose of the rule thus is to assure that no agency of the government will issue directives without first examining the detrimental effects upon the industries subject to it-and receiving the cooperation of other governmental organs. ${ }^{91}$ This represents, of course, another example of how the device of contractual damages is used as an instrument to attain an overall public goal deemed desirable. ${ }^{22}$

\section{The Liability for Members of the Enterprise and Other Third Partics.}

Section $5^{93}$ provides that the enterprise is liable for the acts of all its members in the preparation, execution, and performance of contracts which restit in a failure to conclude the contract within the time prescribed by the plan or generally in a breach. We are accustomed to view a rule like this as creating vicarious liability-liability for the acts of others. But such is not the opinion in East Germany. There the fault of every director, employee, and worker is regarded as the fault of the enterprise itself. Thus the collective interest in the profits of the enterprise-through the enterprise premium fund-is supported by a notion of collective responsibility, based on the following theory: the socialist enterprise is-according to a definition now generally accepted in East Germany ${ }^{94}$ _"a collective of workers and employees with a responsible leader at its top, which the state has organized and to which it has delegated the performance of certain of its tasks. ..." From this concept of a socialist enterprise stems the notion that the workers cannot be regarded as separate legal subjects vis-à-vis the enterprise, while performing their duties within it.05 It is only through the combined activities of these workers that the enterprise comes to act as a unit and as a legal personality bearing responsibility for the injurious acts of its members. ${ }^{96}$ Moreover, the words "in the performance of the contract" are broadly interpreted. Every act of a worker or employec even indirectly connected with the performance of a particular contract thus falls within the scope of section 5.97

(1959). See also Greiner, Die Verantwortlichkeit konsequent durchsetzen, 6 DAS VerThAGSSYSTEM 239 (1962).

91. See Pficke, supra note 66, at 6; Drobnig, supra note 54, at 238.

92. Cf. text at notes $38-48$ supra.

93. Statute of Contracts $\S 5$ :

Verantwortlichkeit des Betriebes für Handlungen seiner Mitarbeiter.

Die Handlungen aller Mitarbeiter des sozialistischen Betricbes bei der Vorbereitung der Vertragsabschlüsse, dem Abschluss der Vertrïge und der Vertragserfüllung bergründen bei Verletzung vorvertraglicher und vertragslicher Pflichten die Verantwortlichkeit des Betriebes.

94. Panzer, Verschulden ist Voraussetzung fïr die vertragliche Verantwortlichlecit, 6 DAs Vertragssystem 196, 200 (1962).

95. Ibid.

96. Panzer, Die Verantwortlichkett für Dritte in deN Vertragsverinälthissen ZWISCHEN SOZIALISTISCHEN WIRTSCHAFTSORGANISATIONEN 68 (Deutsches Institut fïr Rechtswissenschaft, Schriftenreihe Zivilrecht, Heft 9, 1958).

97. See Judgment of May 24, 1960, Zentrales Staatliches Vertragsgericht, 4 DAS VerTRAGSSYSTEM 252, 253 (1960) (Ger. Dem. Rep.). 
Sections $39(1)$ and $39(2){ }^{98}$ also provide responsibility for the acts of third persons, far beyond that previously known in German law. It renders the enterprise liable for the acts of all persons or enterprises with which it cooperated to prepare or perform the contract. For example, section 39 would render an enterprise liable for a breach brought about by the shortcomings of its supplier. The most notable aspect of the provision, however, is that it applies only where the third party can be identified ${ }^{\circ 9}$ and is itself liable to the defendant $;^{100}$ thus it creates liability only where the total damages ultimately can be placed upon the enterprise originally responsible. ${ }^{101}$ This restriction demonstrates quite clearly the view that all contracts between socialist enterprises are but a part of an overall plan, toward the fulfilment of which all enterprises must cooperate.

This interrelationship between the plan and particular contracts is stressed by the "principle of comradely cooperation,"102 expressed in section 4:

The socialistic enterprises are to cooperate as comrades in the preparation, conclusion, and performance of contracts. Each partner is obligated to assist the other partner in the performance of the contract and thus in the implementation of the plan, and must always have regard for the consequences of his own conduct for the fulfillnent by the other partner of his responsibilities under the plan. ${ }^{103}$

This principle is applied in the field of contractual responsibility by requiring the enterprise originally causing the breach to answer not only for the damage caused to the immediate partner but also for the further damage caused because the injured party in turn could not perform its own contractual duties

98. Statute of Contracts $\$ 39$ :

Verantwortlichkeit für Dritte.

(1) Wird die Nichterfüllung oder nicht gehörige Erfüllung von einem Dritten verursacht, für dessen Verhalten der Schuldner dem Gläubiger gegenüber einzustehen hat, so wird der Schuldner von der Verantwortlichkeit nur befreit, wenn weder er gemäss $\$ \S 37$ und 38 noch der Dritte gemäss $\$ \S 37$ bis 39 verantwortlich ist.

(2) Soweit gesetzliche Bestimmungen nichts anderes vorschrciben, hat der Schuldner für das Verhalten des zur Vorbereitung oder Durchführung des Vertragserfüllung herangezogenen Dritten gegenüber dem Glāubiger dann einzustehen, wenn der Dritte, der die Nichterfüllung oder nicht gehörige Erfüllung verursacht hat, feststellbar ist....

99. Statute of Contracts $\$ 39(2)$.

100. Statute of Contracts $\S 39(1)$.

101. Thus the statute adopts the suggestion in Artzt, Zur materiellen Verantworllichkeit bei Schadensverursachung inn Vertragsrecht, 9 NEUE JUSTIz 367, 369 (1955).

102. "Grundsatz der kameradschaftlichen Zusammenarbeit."

103. Statute of Contracts $\$ 4$ :

Grundsatz der Zusammenarbeit.

Die sozialistischen Betriebe haben vor und bei dem Vertragsabschluss und bei de Vertragserfüllung kamaradschaftlich zusammenzuarbeiten. Jeder Partner ist verpflichtet, dem anderen Partner bei der Vertragserfüllung und damit bei der Planerfüllung behilflich zu sein und stets die Ausucirlumgen seincs Verhaltens auf die Planerfïllhng des anderen Partners su berinctsichtigen. (Emphasis added). 
to another enterprise. All enterprises thus are admonished to be aware of the consequences of their mistakes upon the economy as a whole, lest they be required to pay greatly accumulated damages with their harsh effects upon profits. It is this result, especially, that is deemed to make contractual liability for damages a very efficient weapon for enforcing contractual discipline. ${ }^{104}$

The defendant enterprise, however, is prohibited by section 82 from taking recourse against the original party if it could have prevented the original failure. ${ }^{105}$ The purpose of this restriction is to encourage a purchaser, for example, to police its supplier in order to prevent any wasteful breaches. ${ }^{100}$ It clearly reflects a policy of requiring intense cooperation between the enterprises and a nearly complete synchronization of their respective activities.

\section{Penalty Provisions}

Before the passage of the Statute of Contracts, there existed penalty prom visions in the East German laws, but they were independent of damages. When a breach of contract occurred, the injured party obtained the penalty pluts complete compensation. ${ }^{107}$ This former concept of the penalty had one very undesirable aspect: the enterprise that got the full amount of damages in addition to the penalty was better off when its partner did not perform the contract than when the contract was fulfilled. Thus, it was not always induced to assure performance of the contract on behalf of its supplier. ${ }^{108}$ The penalty provision, therefore, could produce satisfactory results only so long as there was strict state control against abuses. When this control weakened and gave way to the principle of a decentralized control of the enterprises by each other, however, the dangers inherent in this concept became more apparent. Instead of serving as an instrument to enforce the fulfillment of contracts, it operated as a temptation to speculate on a breach of contract. A recognition of this led to the present statute, in which the penalty is merely a standardized form of damages for which it is not necessary to prove that injury has occurred or the amount of the damages. ${ }^{109}$ The decisive distinction is that the plaintiff cannot claim in addition to the penalty the full amount of damages, and that he has the burden of proof in claiming damages. ${ }^{110}$ Moreover, to prevent an abuse of the penalty provision by the plaintiff, the contract courts even have the power to reduce the amount of penalties and damages in exceptional cases. ${ }^{111}$

104. PANZER, op. cit. supra note 96 , at $83-84$.

105. Statute of Contracts $\S 82(3)$.

106. Artzt, stipra note 101, at 370; PANZER, op. cit. supra note 96, at 150.

107. PANZER, op. cit. supra note 96, at 46.

108. Cf. Chalfina, Wesen und Bedeutung des Vertrages im Sowjetiscuin Sozialistischen ZivilReCrt 21 (Deutsches Institut für Rechtswissenschaft, Schriftenreilic Zivilrecht, Heft 3, 1958); Pflicke, Materielle Interessierting und Sanktionch, 1 DAS VERTRAGSSYSTEM 5 (Heft (1957). Under the system prevailing prior to the Statute of Contracts, however, such multiple damages were in fact collected only infrequently. Drobnig, supra note 54 , at 239.

109. Statute of Contracts $\$ 35$ (1) ; PANZER, op. cit. supra note 96 , at 46.

110. Statute of Contracts $\S 81(2)$.

111. Statute of Contracts $\S 83$. 
Nevertheless, the penalty is in practice the most important remedy for breach of contract. The statute enumerates the cases in which a penalty is to be paid, including all sorts of delays, lack of quality, insufficient packaging, and complete failure of performance, although the parties also have the right to stipulate penalties for other violations of contractual duties. ${ }^{112}$

With the weakening of the concept of centralized state control, the penalty underwent another substantial alteration. Before the Statute of Contracts, the enterprises were obligated to claim all penalties, ${ }^{113}$ and the defendant enterprise was not entitled to set up a counterclaim against it. ${ }^{114}$ This was the result not only of the educational function of the penalty but also in part of the idea that the penalty was a means of centralized state control. Only when every penalty was successfully claimed, and its payment made through the central bank, could every breach of contract caused by fault be detected. This rigid construction of the penalty, however, has now been somewhat liberalized. Today the enterprises have a high degree of freedom to decide whether or not they want to sue for the penalty. Nevertheless, there still are some cases in which the enterprise is obliged to claim the penalty. Section 79(1) establishes this duty when the delivered goods did not correspond to the stipulated quality, type, and packaging, and when it is expressly provided in other statutes. In all other cases the enterprise has to consider carefully whether the educational purpose of the penalty requires that it be claimed. ${ }^{115}$ Abuses of the discretionary power of the enterprise are prevented by the right of the contract courts to initiate an investigation against enterprises that fail to claim penalties in violation of the law, ${ }^{116}$ and the enterprise can be punished by a fine up to 5,000 Deutsche Mark for repeated violations. ${ }^{117}$ Moreover, because of the strong public interest in the penalty, any agreement by the parties not to claim it or to stipulate either a higher or lower penalty than the statute provides is void,118 and all enterprises must account separately for the amount of damages and penalties paid.119

112. Statute of Contracts $\$ 35(2)$.

113. Hemmerling, Zum Inkraftireten des Gesetzes über das Vertragssystem in der sozialistischen Wirtschaft, 1 DAS VerTRAGSSYSTEAr 1, 5 (Heft 6, 1957). Cf. Pficlic, Materielle Interessierung und materielle Verantworfung, 1 DAS VeRTRAGSSYSTEar 1 (Heft 2, 1957).

114. Drobnig, supra note 54 , at 234.

115. Zentrales Staatliches Vertragsgericht, Grundsätzliche Feststellung Nr. 4/59, cited in Hentschel, Der Schuhgrosshandel mutst das Vertragssystem mur mangelliaft, 4 DAS VerTRAGSSYSTEMr 82 (1960). Cf. Statute of Contracts § 79(3). See generally Hemmerling, stipra note 113 , at 5 .

116. Verordnung über das Staatliche Vertragsgericht (Vertragsgerichtsverordnung) vom 22. Januar 1959 [Regulation concerning the State Contract Court] \& 11(1) (2). [1959]

1 Gesetzblatt der Deutschen Demokratischen Republik 83 (Ger. Dem. Rep.).

117. Regulation concerning the State Contract Court, sipra note 116, $\$ 14(2)$.

118. Judgment of Nov. 25, 1959, Zentrales Staatliches Vertragsgericht, 4 DAS Vertragssystear 91 (1960); Klinger, Zur Hölze der Vertragsstrafe, 3 DAs VertRagsSYSTEM 375 (1959).

119. Hesse, Vertragsstrafen und Schadenersats im Rechnungswesen ausuceisen, 5 DAs VERTRAGSSYSTEMT 340 (1961). 
Since the effects of a money sanction are greater the sooner it is claimed and executed, the penalty provision is ideal. Its amount is fixed in advance by the statute, and a short, quick procedure is available because no injury need be proved. Furthermore, the statute itself encourages a prompt payment: the plaintiff has to claim the penalty within one month, ${ }^{120}$ or, in particular cases, within two weeks. ${ }^{121}$ If the defendant wants to deny his responsibility, this must be done within another month; ${ }^{\mathbf{1 2 2}}$ otherwise he is deemed to have admitted liability. ${ }^{123}$ Finally, payment of the penalty is made easy because all enterprises are subject to the so-called "bill collection procedure." 124 When the debtor is deemed to have admitted liability, the amount of the penalty is transferred by the "Deutsche Notenbank" from his account to the account of the creditor without any further procedure. ${ }^{125}$ Thus a claim for penalties generally can be settled within two months.

\section{Present Practices and Tendencies}

To determine whether the actual effects of the damage provisions in the Statute of Contracts square with the theory is rather difficult, primarily because of the scarcity of statistical data. Nevertheless, some general indications do exist.

All commentators who discuss contractual responsibility agree that the money sanctions for breach of contract have not yet satisfactorily fulfilled the functions which they were thought to serve. ${ }^{126}$ Lengwinat expressed in 1959 the still unanimous opinion "that the sanctions do not exert the leverage which is theoretically ascribed to them."127 The status of contractual discipline is therefore still unsatisfactory. ${ }^{\mathbf{1 2 8}}$ In 1961 , for example, approximately $6,000,000$

120. Statute of Contracts $\$ 77(1)$.

121. Statute of Contracts $\S 77(2)$.

122. Statute of Contracts $\$ 78(1)$.

123. Statute of Contracts $\S 78(3)$.

124. "Rechnungseinzugsverfahren," regulated by the Anordnung über die Verrechnung von Geldforderungen durch Rechnungseinzug (RE-Verfahren) vom 24. Juni 1957 [Dircetive concerning the crediting of money claims through the bill collection procedure]. [1057] 2 Gesetzblatt der Deutschen Demokratischen Republik 229 (Ger. Dem. Rep.).

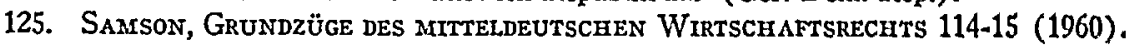

126. Heuer, Demokratischer Zentralismus und sozialistische Moral, 4 Das VentuagsSYSTEM 99, 104 (1960); Hildebrandt, Unsere hohen Vertragsstrafen-ein cristes Signal, 5 Das VerTRAGSSYSTEM 250 (1961); Lengwinat, Zur Verantwortlichkeit fitr Dritte, 3 DAs Vertragssystear 133, 136 (1959); Panzer, Die Amzending des Vertragssystems als sozialistischer Leitungsmethode durch die örtlichen Staatsorgane unt dic Aufgaben der Bezirksvertragsgerichte, 11 STAAT und RECBT 1080, 1083, 1087 (1962); Pflicke, Dic Bedeutung des sozialistischen Bewusstseins und der materiellen Intercssicrtheit bei dir Bekämpfing von Vertragsverletzungen, 4 Das VerTRAGssystem 161, 167 (1960); Spitzner, Zur Entwicklung des Vertragssystems und zur Verbesserung der Arbeit des Stattlichen Vertragsgerichts, 4 Das Vertragssystem 195, 196 (1960).

127. Lengwinat, supra note 126, at 136. "Bekannt ist, dass die Sanktionen nicht dic Hebelwirkung ausüben, die man ihnen abstrakt-theoretisch zuschreibt." Quoted with ap* proval in Heuer, supra note 126, at 104.

128. Spitzner, Die materielle Verantwortlichkeit der Betriebe fiir ihre Kooperationsverpflichtungen, 6 DAs VertragsSYSTEM 193, 194 (1962). 
Deutsche Mark were paid as penalties.120 Considering that the amount of penalties does not exceed $6 \%$ of the value of the goods, ${ }^{130}$ these $6,000,000$ Deutsche Mark must represent many breaches. The main obstacle to the effective working of the system seems still to be the computation of the enterprise premium fund. Money sanctions are very often only one factor among many that affect the profit of the enterprises, ${ }^{131}$ and several of the factors frequently counterbalance each other. ${ }^{132}$ Without going into these technical and economic factors, ${ }^{133}$ suffice it to mention that an extensive investigation of the Central State Contract Court in 1962 led to the conclusion that the sanctions for breach of contract had an insufficient influence on the enterprise premium fund ${ }^{134}$ and that in only a few enterprises did the penalties have any appreciable effect. ${ }^{135}$

But these technical deficiencies are not regarded as crucial or insuperable. The main difficulties arise on a much more substantial level. It is a widespread practice that enterprises do not claim penalties even when they are obliged to do so. The reason seems to be that they do not want to disturb their good will relations with the members of other enterprises or cut off a major source of aid when they themselves are in embarrassing circumstances. ${ }^{130}$ Thus only a few enterprises actually sue for damages beyond the amount of the penalty, ${ }^{137}$ regardless of the prospects for success. Moreover, it is commonly acknowledged that the penalties and damages are regarded as a mere "financial matter," like other general business expenses, which generally are handled by the firm lawyers and accountants. ${ }^{138}$ Indeed the other members of the firm may not even be aware of the payment, ${ }^{139}$ let alone moved to take corrective action. ${ }^{1+0}$

Realization that the contract system does not yet work satisfactorily has led to an extensive discussion during recent years, especially 1962, apparently indicating another shift in the concept of the penalties and damages. The princi-

129. Panzer, supra note 126, at 1087; cf. Hildebrandt, stipra note 126, at 250-51.

130. Statute of Contracts $\S 36(1)$. The value corresponds to the legally imposed price. Judgment of June 24, 1959, Zentrales Staatliches Vertragsgericht, 3 DAS Vertragssysteus 252 (1959).

131. For a discussion of other factors see Otto, Die Wirksamkeit ron Vcrtragsstrafe und Schadenersatz erhöhen, 6 DAS VeRTRAGSSYSTEAr 204, 205 (1962).

132. Pflicke, sipra note 126 , at 167.

133. For further details see Hesse, supra note 119, at 340-41; Sommer, VeriragsstrafenSchadenersatzforderungen und materielle Interessierthcit, 4 DAS VERTRAGSSYSTEMS 84,85 (1960).

134. Panzer, Verschulden ist Voraussetzung fïr die vertragliche Verantwiorllichkcil, 6 DAS VeRTRAGSSYSTEMI 196, 197 (1962).

135. Otto, stpra note 131 , at 205.

136. For a thorough examination see Adamczek \& Alt, Mfissierstandene Lameradseliaftliche Zusammenarbeit, 4 Das Vertragssystear 69, 70 (1960).

137. Kleine, Der Schadenersatz in Verfahren vor dem Staatlichen Vertragsgerieht, 6 DAs VeRTRAgssysteM 201 (1962).

138. Panzer, supra note 126, at 1087; Hildebrandt, sipra note 126, at 250; Spitzner, supra note 126, at 196.

139. Cf. Heuer, supra note 126 , at 104.

140. Spitzner, sipra note 126, at 196. 
ple of material interest is increasingly regarded as insufficient to achieve the desired results. The main criticism is that it shows only an individual worker the immediate consequences of his failure, but demonstrates no more farreaching political consequences to the society as a whole. ${ }^{141}$ Furthermore, it is suggested that there can be no automatic "moral" effect from the money sanctions so long as they refer only to a "material interest." 142 The hope is that "education through the Mark" can be turned into an ideological education, ${ }^{140}$ whereby the breach of contract tends not to be a mere economic matter, but instead becomes a "matter of honor," a "moral question."144

The most controversial point of discussion at the moment is the fault principle. While certain authors still adhere to it as the basis of contractual responsibility, ${ }^{145}$ another very influential group favors a change, ${ }^{140}$ feeling that the fault principle as it now exists merely encourages the enterprises to seek defenses against their liability ${ }^{147}$ and to emphasize their individual abilities over the overall goals of the plan. The question, as the critics see it, is whether it is possible to find a principle of responsibility that does not presuppose fault but has, nevertheless, an educational effect.148 One notable commentator suggests that the decisive criterion for imposing liability in the absence of fault should be whether a modification of the practice is necessary and can be accomplished by the action of the defendant enterprise. ${ }^{140}$ The needs of the society and objective standards are thus the only relevant factors, and individual abilities are disregarded completely. Whether these proposals will be successful is not yet clear, but they are the main topics of discussion, and have already given rise to a pending motion to reform the statute in the Counsel of Ministers of East Germany. ${ }^{150}$

\section{Conclusion}

When we evaluate the system of money sanctions for breach of contract as a whole, the interrelation with its economic basis, the economic necessities, the underlying policies, and the technical devices, it seems clear that it is a highly logical construction. Logical clarity, indeed, seems to be the most distinguishing technical feature of communist legal institutions. They are not drawn from historical experience, but intellectually conceived, purportedly with no am-

141. Heuer,' supra note 126, at 104-05; Pflicke, supra note 126, at 167.

142. Heuer, silpra note 126, at 104.

143. Pflicke, supra note 126 , at 167.

144. Id. at 165 .

145. Kleine, supra note 137, at 202; Panzer, supra note 134, at 199.

146. Heuer \& Pflicke, Zu den Aufgaben der Rechtswissenschaft bei der Verbesscrin!! der Zusammenarbeit der Betriebe, 4 DAS VertragssysteM 204, 209 (1960); Pflicke, Z̈u den stbjektiven Voraussetzungen der wechselseitigen materiellen Verantwortlichlecit der sozialistischen Betriebe, 6 DAS VerTRAGSSYSTEMr 225 (1962); Spitzner, supra note 128, at 196.

147. Spitzner, supra note 128, at 196; cf. Pflicke, supra note 126, at 167 .

148. Pflicke, stpra note 146 , at 228.

149. Id. at $228,233$.

150. Spitzner, supra note 128 , at 193. 
biguities, irrationalities, contradictions, and ancient relics. They result from the precise translation of basic economic and philosophical principles into legal terms, the perfect compliance of the law with the demands of a peculiar economic system, which is in turn the result of a definite philosophical concept. Together they form a closed system of doctrines and thoughts, behind which lurks the idea that there are no existential contradictions in life and society; that an answer to every question can be found by logical operations. The most obvious consequence of this structure of the law is that we can trace every legal provision right back to its ideological and economic roots, and that by studying even the most technical fields of law we can quickly reach basic political and philosophical principles. Every ideological change sooner or later finds its expression in even the most remote legal provision. Thus, the study of communist law is always at the same time a study of the communist ideology.

Besides these, another feature of communist law stands out-the relation between collective and personal responsibility. The idea of collective responsibility is at the basis of the system of contracts, and is most clearly expressed by the enterprise premium fund and the concept of the socialist enterprise. It is the performance of the collective as a whole that determines the status of its members. Every worker participates-at least in theory-in the success and failure of "his" enterprise; his acts, in turn, have an immediate influence on the status of his fellow worker, and vice versa. The opposition between management and workers and among the workers themselves seems completely abolished; they all are submitted to the same social aim expressed in the plan, and they all contribute equally to it, although in different functions. The same is true of the enterprises among themselves. They are woven into a close net of reciprocal relations, every enterprise being important only in view of the overall output of all enterprises. But this concept of collective responsibility is only one side of the picture, for combined with it is the highest possible notion of personal responsibility, a categorical demand for the highest of human values from each member of the collective. The collective system can work satisfactorily only when it consists of men that develop their talents to the utmost, demand even the greatest exertions from themselves, but, nevertheless, submit completely to the exigencies of the society. The man without fault, without weaknesses, able to match every situation, who at the same time identifies his interest with that of the nation and achieves the highest social discipline ${ }^{151}$ is the "Leitbild," the standard of this law. What we might consider as the ideal-well knowing that we could never reach it-is here deemed the standard, the type of man that must, and even more optimistically, can be achieved. The concept seems to us to be that of a man who incorporates the highest human values only to become a tool in the hands of society. But the communist legal philosophers see no such contradiction. Their legal institutions are based on the principle that personal interests always conform to those of

151. Cf. Grzybowskn, Soviet Legal Institutions 110-18 (1962). 
society. ${ }^{152}$ The law of money sanctions for breach of contract is a superb example of the practical consequences of this basic principle.

But even the communist legislator cannot avoid recognizing that there still remains a wide gap between his concept of the ideal man, and man as he really is. The final aim of the educational thrust ${ }^{\mathbf{1 5 3}}$ of the law is to close this gap-to produce, ultimately, a new type of man, the "homo sovieticus,"154 who is indispensable to the collective system as a whole.

152. SAMSON, op. cit. supra note 125, at 118; see generally 1 GeNKIN, BRATUs, LuNZ \& NowIZKI, SowJeTISCHES ZTVILRECHT 18-19 (1953).

153. As to this educational aspect of communist law, see Grzyrowsk1, op. cit. supra note 151, at 118-29.

154. Id. at $110-18$. 